\title{
Development of a One-Step Real-Time Polymerase Chain Reaction Assay for Diagnosis of Phytophthora ramorum
}

\author{
Kelvin J. D. Hughes, Jennifer A. Tomlinson, Ruth L. Griffin, Neil Boonham, Alan J. Inman, and Charles R. Lane
}

Central Science Laboratory, Sand Hutton, York, North Yorkshire, YO41 1LZ, U.K.

Accepted for publication 1 April 2006.

\begin{abstract}
Hughes, K. J. D., Tomlinson, J. A., Griffin, R. L., Boonham, N., Inman, A. J., and Lane, C. R. 2006. Development of a one-step real-time polymerase chain reaction assay for diagnosis of Phytophthora ramorum. Phytopathology 96:975-981.

Phytophthora ramorum is a recently described pathogen causing bleeding cankers, dieback, and leaf blight on trees and shrubs in parts of Europe and North America, where the disease is commonly known as sudden oak death. This article describes the development of a singleround real-time polymerase chain reaction (PCR) assay based on TaqMan chemistry, designed within the internal transcribed spacer 1 region of the nuclear ribosomal (nr)RNA gene for detection of $P$. ramorum in plant material. Unlike previously described methods for the molecular detection of $P$. ramorum, this assay involves no post amplification steps or multiple rounds of PCR. The assay was found to have a limit of detection
\end{abstract}

ABSTRACT

of $10 \mathrm{pg}$ of $P$. ramorum DNA, and could detect $P$. ramorum in plant material containing $1 \%$ infected material by weight within 36 cycles of PCR. The assay also was used to test DNA from 28 other Phytophthora spp. to establish its specificity for $P$. ramorum. A quick and simple method was used to extract DNA directly from host plant material, and detection of $P$. ramorum was carried out in multiplex with an assay for a gene from the host plant in order to demonstrate whether amplifiable DNA had been extracted. Amplifiable DNA was extracted from $84.4 \%$ of samples, as demonstrated by amplification of host plant DNA. The realtime protocol was used to test 320 plant samples (from 19 different plant species) from which DNA extraction had been successful, and was shown to give results comparable with a traditional isolation technique for diagnosis of $P$. ramorum in plant material from common U.K. hosts.

Additional keywords: rhododendron, viburnum.
In the United States, Phytophthora ramorum causes mortality of native American oak trees (Lithocarpus densiflorus and Quercus spp.) in woodlands on the west coast (24). This pathogen also causes dieback or leaf blight on a wide range of other woodland trees, shrubs, and several herbaceous plant species and has been found in nurseries in a number of states (6). In Europe, it is recorded mainly in nurseries, where the most commonly reported hosts are rhododendron (18,34), viburnum (19), and camellia (2). However, a wider range of other host species has been reported which includes Hamamelis virginiana (11), Pieris formosa (14), Syringa vulgaris (3), and Taxus baccata (20). Phytophthora ramorum also has been recorded on several native and nonnative tree species in the United Kingdom, causing either bleeding bark cankers (e.g., Aesculus hippocastanea, Fagus sylvatica, Q. cerris, Q. falcata, and Q. rubra) or leaf and shoot infections (e.g., Castanea sativa and $Q$. ilex) $(4,5)$. In both the United States and Europe, $P$. ramorum is considered an exotic pathogen which has been introduced separately on each continent $(15,26)$. European isolates and North American woodland isolates generally represent two distinct populations (15). Isolates from the European population are almost all of the A1 mating type, although a single European A2 isolate is known from Belgium (32); isolates from North America all have been reported as the A2 mating type, except for isolated outbreaks in nurseries in Oregon, Washington State, and British Colombia (26). Due to the potential threat to trees, woodlands and heathlands, emergency European Commission phytosanitary measures were implemented in November 2002 to prevent the introduction and spread of $P$. ramorum within the European Union (1). Therefore, development of reliable,

Corresponding author: K. J. D. Hughes; E-mail address: k.hughes@csl.gov.uk

DOI: 10.1094/PHYTO-96-0975

(C) 2006 The American Phytopathological Society accurate, and rapid diagnostic methods for symptomatic tissue became essential. Diagnosis of $P$. ramorum can be performed using traditional mycological methods involving isolation from host material followed by morphological identification with microscopy in comparison with a published description of the organism (33). However, this relies on key taxonomic features being present and skilled mycologists to differentiate $P$. ramorum from the potential range of other Phytophthora spp.; if these taxonomic features are absent, overlooked, or misidentified, this may lead to an incorrect diagnosis. Additionally, successful isolation may be dependent on factors such as the time of year (7). Diagnosis using conventional polymerase chain reaction (PCR) can support traditional morphological approaches, and such methods have been developed for $P$. ramorum using primers designed for the internal transcribed spacer (ITS) 1 and 2 regions of the nuclear ribosomal gene for $P$. ramorum $(10,18)$ and subunit 1 and 2 of the mitochondrial cytochrome oxidase gene (22). Gelbased molecular detection methods such as single-strand conformation polymorphism (SSCP) analysis (17) and restriction fragment length polymorphism (RFLP) analysis (21) also can be used to identify $P$. ramorum from other Phytophthora spp., but such systems can be difficult to interpret and are not suited to the highthroughput testing that is necessary for national surveys.

Real-time PCR assays (27), especially those based on TaqMan chemistry, are becoming increasingly preferred to gel-based PCR because they are quicker, generally offer increased specificity and sensitivity, and are performed in a closed tube system which is less prone to post-PCR contamination $(9,23,30)$. TaqMan assays amplify DNA in the same way as conventional PCR but exploit a dual-labeled fluorescent probe (designed to hybridize to the DNA sequence between the forward and reverse primers) and the $5^{\prime}-3^{\prime}$ exonuclease activity of Taq polymerase to produce a fluorescent signal. As amplification occurs, the probe is cleaved in a sequencespecific fashion resulting in an increase in fluorescence propor- 
TABLE 1. Results following real-time polymerase chain reaction testing of a range of Phytophthora isolates with primers designed to the internal transcribed spacer $5.8 \mathrm{~S}$ region and to $P$. ramorum $^{\text {a }}$

\begin{tabular}{|c|c|c|c|c|}
\hline \multirow[b]{2}{*}{ Species tested } & \multirow[b]{2}{*}{ Reference } & \multicolumn{3}{|c|}{$\mathrm{Ct}$ value, amplification using } \\
\hline & & $\begin{array}{c}5.8 \mathrm{~S} \\
\text { primers }\end{array}$ & $\begin{array}{c}\text { Pram- } \\
114 \mathrm{~F}\end{array}$ & $\begin{array}{l}\text { Pram- } \\
114 \mathrm{Fc}\end{array}$ \\
\hline P. boehmeriae & P $6950^{b}$ & 16.28 & - & - \\
\hline P. boehmeriae & CBS $100410^{c}$ & 16.56 & - & - \\
\hline P. botryosa & P $6945^{\mathrm{b}}$ & 18.04 & - & - \\
\hline P. cactorum & MUCL9638 & 17.93 & - & - \\
\hline P. cactorum & CSL $2151^{\mathrm{e}}$ & 18.09 & - & - \\
\hline P. cambivora & CBS $376.61^{\mathrm{c}}$ & 16.60 & - & - \\
\hline P. cambivora & FR P315 & 17.06 & - & - \\
\hline P. cinnamomi & SCRI CIN5g & 16.03 & - & - \\
\hline P. cinnamomi & PD 93/1389h & 16.23 & - & - \\
\hline P. citricola & CSL $1531^{\mathrm{e}}$ & 16.25 & - & - \\
\hline P. citricola & CSL 2098e & 16.43 & - & - \\
\hline P. citricola & SCRI CIT19 & 16.86 & - & - \\
\hline P. citricola & CSL $1530^{\mathrm{e}}$ & 17.07 & - & - \\
\hline P. citricola & CBS379.61 & 17.14 & - & - \\
\hline P. citrophthora & IMI $132217^{i}$ & 16.07 & - & - \\
\hline P. cryptogea & SCRI P521g & 16.95 & - & - \\
\hline P. erythroseptica & P $7889^{b}$ & 18.02 & - & - \\
\hline P. europaea & CBS $109053^{c}$ & 17.39 & - & - \\
\hline P. fragariae var. rubi & FR-163 & 16.77 & - & - \\
\hline P. gonopodyides & P $10337^{b}$ & 16.28 & - & - \\
\hline P. heveae & CBS $958.87^{c}$ & 17.04 & - & - \\
\hline P. hibernalis & P $3822^{\mathrm{b}}$ & 17.45 & - & - \\
\hline P. ilicis & P $3939^{b}$ & 17.37 & - & - \\
\hline P. insolita & P $6195^{\mathrm{b}}$ & 17.65 & - & - \\
\hline P. kernoviae & FR CAE36B ${ }^{f}$ & 16.94 & - & - \\
\hline P. kernoviae & CSL 2169e & 16.98 & - & - \\
\hline P. kernoviae & CSL 2306 & 17.15 & - & - \\
\hline P. kernoviae & FR CAE4 ${ }^{\mathrm{f}}$ & 17.61 & - & - \\
\hline P. kernoviae & FR P1560 f & 17.88 & - & - \\
\hline$P$. lateralis & P $3888^{\mathrm{b}}$ & 18.69 & 32.55 & - \\
\hline$P$. lateralis & P $1728^{b}$ & 16.96 & 31.07 & 38.95 \\
\hline P. macrochlamydospora & P $10263^{b}$ & 17.10 & - & - \\
\hline P. megasperma & CBS $320.49^{c}$ & 16.26 & - & - \\
\hline P. nemorosa & P $10288^{b}$ & 17.18 & - & - \\
\hline P. nicotianae & CBS $411.87^{c}$ & 17.72 & - & - \\
\hline P. nicotianae & SCRI NIC19 & 16.48 & - & - \\
\hline P. palmivora & SCRI P488g & 17.50 & - & - \\
\hline P. pseudosyringae & CSL2369e & 15.79 & - & - \\
\hline P. pseudosyringae & P $10444^{\mathrm{b}}$ & 16.15 & - & - \\
\hline P. quercina & P $10334^{\mathrm{b}}$ & 17.10 & - & - \\
\hline P. ramorum (Germany) & BBA $69082^{k}$ & 18.51 & 15.79 & 22.44 \\
\hline P. ramorum (Germany) & BBA $14 / 98 a^{k}$ & 18.04 & 15.36 & 22.11 \\
\hline P. ramorum (U.K.) & CSL $1684^{\mathrm{e}}$ & 17.55 & 15.37 & 22.26 \\
\hline P. ramorum (U.K.) & CSL $1667^{\mathrm{e}}$ & 19.73 & 16.94 & 24.07 \\
\hline P. ramorum (U.S.A.) & $\mathrm{P} 1349^{\mathrm{k}}$ & 17.94 & 15.35 & 21.96 \\
\hline P. ramorum (U.S.A.) & P1403' & 19.27 & 16.33 & 22.81 \\
\hline P. ramorum (U.S.A.) & $\mathrm{P} 1347^{\mathrm{f}}$ & 19.54 & 16.55 & 23.90 \\
\hline P. ramorum $\mathrm{EU}$ A $1^{\mathrm{m}}$ & $\mathrm{P} 1376^{\mathrm{f}}$ & 17.22 & 15.12 & 21.33 \\
\hline$P$. ramorum US A $2^{\mathrm{n}}$ & $\mathrm{P} 1579^{\mathrm{h}}$ & 17.79 & 16.32 & 23.21 \\
\hline P. richardiae & P 7788 & 17.12 & - & - \\
\hline$P$. richardiae & $\mathrm{P} 10335^{\mathrm{b}}$ & 17.77 & - & - \\
\hline$P$. richardiae & P 7789 & 17.80 & - & - \\
\hline P. syringae & CBS $272.55^{\mathrm{c}}$ & 16.34 & - & - \\
\hline P. syringae & $4 \mathrm{~N} 0247-5^{\mathrm{j}}$ & 16.53 & - & - \\
\hline P. syringae & 4N0247-6 & 16.93 & - & - \\
\hline P. syringae & CBS $364.52^{c}$ & 17.84 & - & - \\
\hline P. uliginosa & CBS $109055^{\mathrm{c}}$ & 17.25 & - & - \\
\hline
\end{tabular}

${ }^{\text {a }}$ Country of isolation for P. ramorum is indicated where known. Cycle threshold $(\mathrm{Ct})$ values are mean values for duplicate reactions; - indicates a negative result. b M. Coffey, University of California.

c CBS, Utrech, The Netherlands.

d Belgian Co-ordinated Collections of Micro-organisms.

e Central Science Laboratory, York, U.K.

${ }^{f}$ Forest Research, Alice Holt, Farnham, U.K.

g D. Cooke, SCRI, U.K.

${ }^{\text {h }}$ H. de Gruyter, Dutch Plant Protection Service, Wageningen, The Netherlands.

i CABI, Egham, U.K.

j Laboratoire National de la Protection des Vegataux, Nancy, France.

${ }^{k} \mathrm{~S}$. Werres, BBA, Braunschweig, Germany.

${ }^{1}$ E. Hansen, University of Oregon.

${ }^{\mathrm{m}}$ Confirmed as A1 mating strain by Forest Research.

${ }^{\mathrm{n}}$ Confirmed as A2 mating strain by Forest Research. tional to the amount of product amplified. The number of cycles it takes for a sample to produce fluorescence exceeding a threshold value is referred to as the cycle threshold $(\mathrm{Ct})$ value and can be used to compare amplification between samples. The ability of real-time machines like the ABI Prism 7900HT (Applied Biosystems, Foster City, CA) to measure fluorescence at various wavelengths simultaneously allows reactions to be multiplexed using different dye labels, allowing internal control assays to be combined with target-specific assays (31).

A nested real-time PCR assay has been developed for the specific detection of $P$. ramorum (12), based on SYBR green technology. Because the protocol is a nested PCR, an initial PCR step is performed prior to the real-time PCR step. However, because the assay comprises multiple steps, it may be prone to contamination introduced between the first and second round of PCR. Also, because the assay is based on SYBR green dye, it is necessary to perform melting profile analysis to ascertain whether amplification was specific or due to accumulation of primer dimers or nonspecific amplification products. This article describes a streamlined, single-round real-time PCR assay for the specific detection of P. ramorum. A simple procedure was used for extraction of DNA from cultures and host plant material which, unlike some previously described methods, does not require use of organic solvents or pre-freezing or lyophilization of tissue, making it potentially suitable for use in a routine diagnostic setting. $P$. ramorum-specific primers and probe were used in multiplex with generic plant cytochrome oxidase (COX) primers and probe to allow detection of host plant DNA, helping to safeguard against false-negative results. Of 379 samples submitted for testing, DNA was successfully extracted from 320 samples (84.4\%) of 19 different plant species. The 320 samples were tested for $P$. ramorum using the real-time detection method and the results were found to compare favorably with isolation and morphological identification.

\section{MATERIALS AND METHODS}

Maintenance of isolates. In all, 57 isolates from 29 different Phytophthora spp. were obtained from around the world (Table 1). The species name provided by the isolate supplier was adopted as the isolate's identity and isolates were maintained on carrot piece agar (CPA) (33) at $\approx 20^{\circ} \mathrm{C}$ under $12 \mathrm{~h}$ of light and $12 \mathrm{~h}$ of dark, or underwater at $4^{\circ} \mathrm{C}$ in the Central Science Laboratory (CSL) culture collection until required. Some isolates also were grown for 2 weeks on $4 \%$ potato dextrose agar (PDA) at $\approx 20^{\circ} \mathrm{C}$ under $12 \mathrm{~h}$ of light and $12 \mathrm{~h}$ of dark to obtain DNA for sequencing. Prior to use, samples of each batch of CPA were subjected to the DNA extraction protocol described below and tested using the $5.8 \mathrm{~S}$ real-time PCR assay to ensure the absence of any amplifiable Phytophthora DNA within the medium.

Extraction of DNA from cultured isolates. DNA extraction from cultures was performed using a NucleoSpin Plant extraction kit (Macherey-Nagel, Düren, Germany). Each isolate was grown for 2 weeks on CPA; then, $1-\mathrm{cm}^{2}$ plugs were taken from each isolate, avoiding pieces of carrot within the agar. Each plug was placed in a 2-ml microcentrifuge tube; then, a similar volume of sterile 0.5-mm glass beads (BioSpec Products Inc., Bartlesville, OK) was added, along with $300 \mu \mathrm{l}$ of NucleoSpin $\mathrm{C} 1$ buffer. Tubes were sealed with a screw-cap lid containing an o-ring and shaken in a MiniBeadbeater-8 homogenizer (BioSpec Products Inc.) for $3 \mathrm{~min}$ on quarter power to macerate the sample. DNA extraction was completed following the NucleoSpin Plant kit support protocol for fungi. Where relevant, DNA was quantified spectrophotometrically.

ITS sequencing. Phytophthora isolates were grown for 2 weeks on $4 \%$ PDA as described; then, DNA was extracted using the NucleoSpin method and the ITS and 5.8S regions were amplified using PCR, as described previously (13), and sequenced. The following accessions were deposited in GenBank: P. citricola 
isolates CSL cc1530/P920 (AY769941) and CSL cc1531/P1013 (AY769942); P. kernoviae isolate CSL cc2124 (DQ002008); P. lateralis isolate CSL cc2090/CBS168.42 (AY785952); and $P$. ramorum isolates CSL cc1527/P1367 (AY785958), CSL cc1528/P1347 (AY785959), and CSL cc1529/P1348 (AY785960).

TaqMan probe and primer design. Multiple sequence alignments were performed on new sequences and sequences from GenBank using the Clustal V method from the MegAlign program (DNAStar Inc., Madison, WI). Probes and primers for P. ramorum were designed within the most divergent sequence regions identified among species in the ITS 1 region of the nuclear ribosomal (nr)RNA gene (Fig. 1). The probe and primer combinations were designed using Primer Express software (Applied Biosystems, Foster City, CA) and modifications to these designs subsequently were introduced with the intention of improving discrimination between $P$. ramorum and other Phytophthora spp. with similar sequences $(25,29)$ (Fig. 1). Primer and probe sequences, and probe reporter and quencher dyes, are shown in Table 2. Primers and a TaqMan probe also were designed within the $5.8 \mathrm{~S}$ region of the nuclear ribosomal (nr)RNA gene (Table 2) from several Phytophthora spp. (alignment not shown). These acted as a control assay showing that amplifiable DNA was extracted from all Phytophthora isolates tested. Plant internal control primers and probe were based on a previously described assay designed in a conserved region of the plant COX gene (31). Primers were synthesized by TagN (Newcastle, England) and probes were synthesized by Applied Biosystems.

Real-time PCR. Real-time PCRs were set up in 96-well reaction plates using TaqMan Universal PCR Master Mix or TaqMan
Core Reagents (Applied Biosystems) consisting of $1 \times$ buffer A (50 mM KCl, $10 \mathrm{mM}$ Tris- $\mathrm{HCl}, \mathrm{pH} 8.3$, ROX passive reference dye) and AmpliTaq Gold at $0.025 \mathrm{U} / \mu \mathrm{l}$, plus $0.2 \mathrm{mM}$ each $\mathrm{dNTP}$ and $5.5 \mathrm{mM} \mathrm{MgCl}_{2}$. For each reaction, $1 \mu \mathrm{l}$ of DNA extract was added, giving a final volume of $25 \mu \mathrm{l}$, and negative controls containing nuclease-free water instead of DNA were included in every run. When testing DNA extracted from cultures, reactions contained either $P$. ramorum or $5.8 \mathrm{~S}$ primers and probe at final concentrations of $300 \mathrm{nM}$ for each primer and $100 \mathrm{nM}$ for the probe. When testing DNA extracted from plant material, multiplex reactions containing $P$. ramorum primers (300 $\mathrm{nM}$ each) and probe $(100 \mathrm{nM})$ and COX primers $(200 \mathrm{nM}$ each) and probe $(100 \mathrm{nM})$ were used. Real-time PCR was carried out on an ABI Prism 7900HT (Applied Biosystems) using generic cycling conditions $\left(50^{\circ} \mathrm{C}\right.$ for $2 \mathrm{~min}, 95^{\circ} \mathrm{C}$ for $10 \mathrm{~min}$, and 40 cycles of $95^{\circ} \mathrm{C}$ for $15 \mathrm{~s}$ and $60^{\circ} \mathrm{C}$ for $1 \mathrm{~min}$ ). The $\mathrm{Ct}$ value for each reaction was assessed using the Sequence Detection Software's default threshold setting of $0.2 \Delta \mathrm{Rn}$ (fluorescence) units.

Production of artificially infected plant material. Detached healthy leaves and stems of Rhododendron ponticum and Viburnum tinus and leaves of a Camellia sp. were wounded and inoculated with $0.5-\mathrm{cm}^{2}$ plugs taken from the margin of 7-day-old cultures of $P$. ramorum on CPA (CSL isolate ref. 1604). Inoculated material then was incubated in a damp chamber at room temperature for 7 days to initiate infection.

Extraction of DNA from plant material. DNA was extracted from artificially and naturally infected plant material. Weighed samples $(0.2$ to $0.5 \mathrm{~g})$ were placed in extraction bags (Bioreba, Reinach, Switzerland) with 8 to 10 volumes of NucleoSpin C1

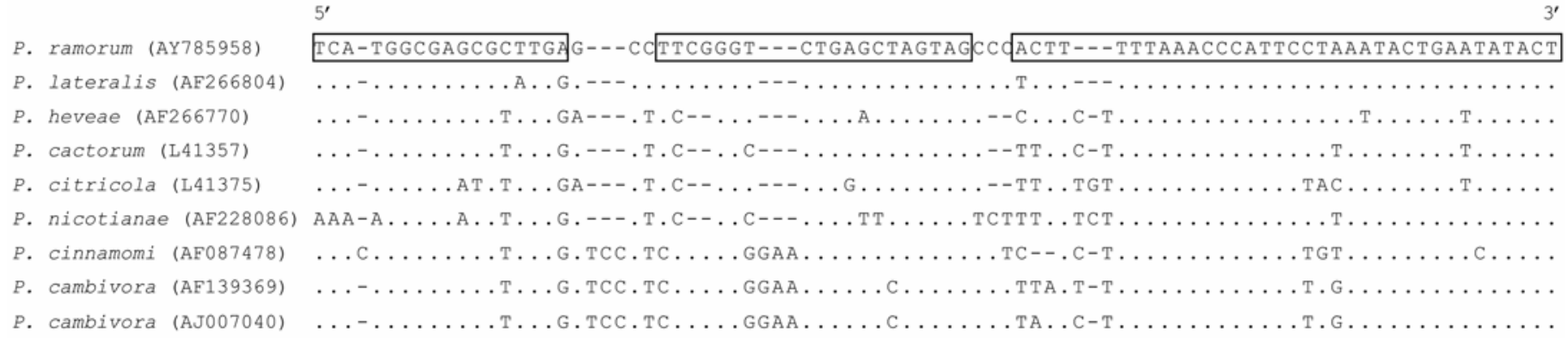

Fig. 1. Multiple sequence alignment for a range of Phytophthora spp. to which the Phytophthora ramorum-specific assay was designed. Boxes identify the position of the primers and probe; - indicates nucleotides identical to the P. ramorum sequence and - indicates nucleotides not present. The 5' and $3^{\prime}$ nucleotides for each of the sequences in the alignment are as follows, AY785958 (104-171), AF266804 (93-160), AF266770 (86-151), L41357 (100-166), L41375 (135200), AF228086 (128-196), AF087478 (145-219), AF139369 (115-190), and AJ007040 (145-220). Additional sequences compared but not included in the figure were P. ramorum (AY785959, AY785960, AY038050, AY785955, and AY785956), P. boehmeriae (AF228076), P. cactorum (AF087480, AF228077, and AF266772), P. cambivora 1 (AF087479), P. cambivora 2 (AF266763); P. cinnamomi (AF266764), P. citricola (AY769942, AY785954, and AY769941), P. idaei (CSL 1366), P. lateralis (AF287256), P. nemorosa (AY332654), P. nicotianae (AF228086, AF228085, and AF228085), P. pseudosyringae (AY366462 and AY366463), and P. kernoviae (CSL 2124).

TABLE 2. Characteristics of primers and TaqMan probes ${ }^{\mathrm{a}}$

\begin{tabular}{|c|c|c|c|c|c|}
\hline Primer or probe & Sequence $\left(5^{\prime}-3^{\prime}\right)$ & $\begin{array}{c}\text { Position of } 5^{\prime} \\
\text { base in sequence }\end{array}$ & $\begin{array}{c}\text { Reporter } \\
\left(5^{\prime}\right)^{\mathrm{b}}\end{array}$ & $\begin{array}{l}\text { Quencher } \\
\left(3^{\prime}\right)^{\mathrm{b}}\end{array}$ & $\begin{array}{l}\text { Final concentration } \\
(\mathrm{nM})\end{array}$ \\
\hline Pram-114F & TCATGGCGAGCGCTTGA & 104 & $\ldots$ & $\ldots$ & 300 \\
\hline Pram $-114 \mathrm{Fc}$ & TCATGGCGAGCGCTGGA & 104 & $\ldots$ & $\ldots$ & 300 \\
\hline Pram probe & TTCGGGTCTGAGCTAGTAG & 124 & FAM & TAMRA & 100 \\
\hline $\mathrm{COXF}$ & CGTCGCATTCCAGATTATCCA & 1,488 & $\ldots$ & $\ldots$ & 200 \\
\hline $\operatorname{COX} \mathrm{R}_{\mathrm{W}}$ & CAACTACGGATATATAAGRRCCRRAACTG & 1,566 & $\ldots$ & $\ldots$ & 200 \\
\hline COX probe & AGGGCATTCCATCCAGCGTAAGCA & 1,534 & VIC & TAMRA & 100 \\
\hline $5.8 \mathrm{~S}$ probe & ACGCTGCGAACTGCGATACGTAATGC & 258 & JOE & BHQ1 & 100 \\
\hline
\end{tabular}

a Table shows the sequence and position of the primers and probes and fluorescent dyes used. The position of the $5^{\prime}$ bases of the forward and reverse primers and the probes are relative to the sequence accession AY785958 for the Phytophthora ramorum and 5.8S assays, and in the sequence accession X83206 for the cytochrome oxidase (COX) internal control assay.

${ }^{\mathrm{b}}$ FAM $=$ 6-carboxyfluorescein, TAMRA $=$ tetra-methylcarboxyrhodamine, VIC $=$ Applied Biosystems, Foster City, CA, JOE = 6-carboxy-4,5-dichloro-2,7dimethoxyfluorescein, and BHQ1 = Black Hole Quencher 1, Biosearch Technologies, Novato, CA. 
buffer. Each sample then was homogenized using a Homex grinder (Bioreba) and DNA was extracted from 300- $\mu$ aliquots using the NucleoSpin method described above. For the comparative testing of symptomatic plant material, samples of $\approx 0.2 \mathrm{~g}$ wet weight were ground in $1.6 \mathrm{ml}$ of Nucleospin $\mathrm{C} 1$ buffer.

Isolation of Phytophthora spp. from plant material. Plant material (leaf or stem) with suspected symptoms was collected by Defra's Plant Health and Seeds Inspectorate (PHSI) and placed in a sealed plastic bag with a small piece of damp tissue prior to dispatch from the field. On receipt in the laboratory, samples were examined for the presence of typical lesions; small pieces of tissue were aseptically excised from the leading edge of the lesions. These were placed in a small plastic bag with $\approx 50 \mathrm{ml}$ of distilled water for $\approx 1 \mathrm{~h}$ to aid rehydration, during which time the bags were shaken vigorously for 15 to $20 \mathrm{~s}$ to remove any debris. At the end of the hour, the water was changed twice to remove debris that had been dislodged by the washing process. The tissue then was plated out onto a semiselective agar $\left(\mathrm{P}_{5} \mathrm{ARP}(\mathrm{H})\right)(16)$ and the plates were examined microscopically after 6 days incubation $\left(\approx 20^{\circ} \mathrm{C}, 12 \mathrm{~h}\right.$ of light and $12 \mathrm{~h}$ of dark) for the presence of any Phytophthora sp. and, specifically, $P$. ramorum growth.

\section{RESULTS}

TaqMan probe and primer design. Primers and a TaqMan probe were designed (Table 2) to the most species-specific region identified in the ITS 1 region following a multiple sequence alignment between $P$. ramorum and some of the most closely related Phytophthora spp. (Fig. 1). In addition to primer Pram-114F, which matched the sequence of $P$. ramorum, a second forward primer was designed (Pram-114Fc) which included a base substitution at the third base from the $3^{\prime}$ end (guanine instead of thymine) in order to make the primer sequence more distinct from the ITS target sequence of closely related species. A real-time assay also was designed within the conserved region of the $5.8 \mathrm{~S}$ sequence of the nrRNA gene to allow the detection of DNA for all Phytophthora spp. tested.

Assay specificity. In all, 57 isolates of 29 different species of Phytophthora were tested using the $P$. ramorum real-time assay and the $5.8 \mathrm{~S}$ control assay (Table 1). Results of the $5.8 \mathrm{~S}$ assay

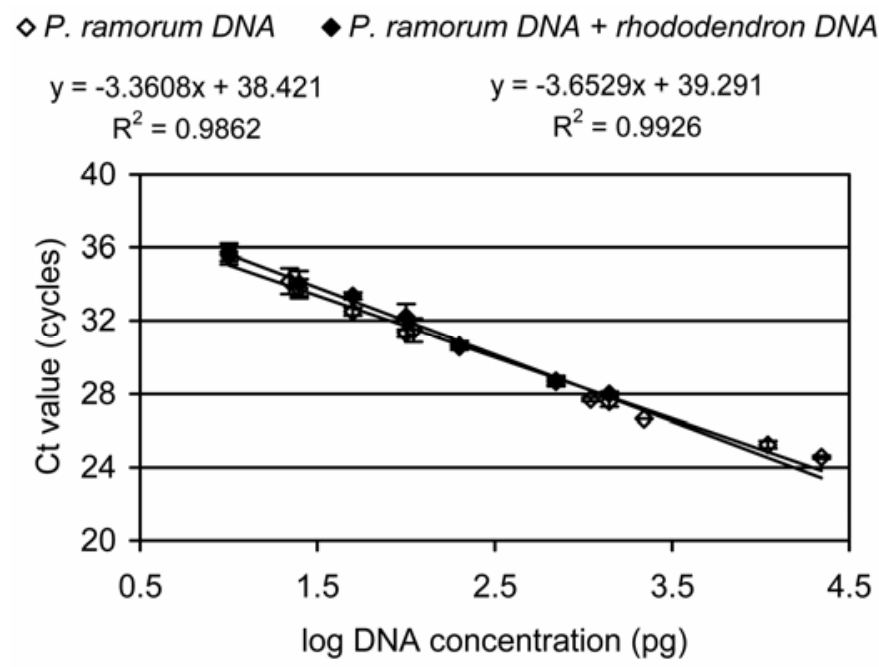

Fig. 2. Linear relationship between DNA concentration and cycle threshold (Ct) value for Phytophthora ramorum DNA amplified using TaqMan primers and probe. A dilution series of DNA extracted from $P$. ramorum culture was tested by real-time polymerase chain reaction using the $P$. ramorum assay (primers Pram-114Fc and 190R). The same dilutions also were tested with the addition of $\approx 5 \mathrm{ng}$ of DNA extracted from healthy rhododendron leaf per $25 \mu \mathrm{l}$ of reaction. $\mathrm{Ct}$ values shown are mean values for three replicate reactions; error bars show standard deviations. showed that all extracts contained amplifiable DNA, with $\mathrm{Ct}$ values varying between 16.03 and 19.73 (estimated using a standard curve as corresponding to $\approx 10$ to $100 \mathrm{ng}$; data not shown). $P$. ramorum isolates gave $\mathrm{Ct}$ values between 15.12 and 16.94 when tested with the $P$. ramorum assay incorporating the Pram $114 \mathrm{~F}$ primer, and between 21.33 and 24.07 when tested using the Pram-114Fc primer. All other Phytophthora isolates tested negative with both $P$. ramorum primer sets, with the exception of $P$. lateralis (Table 1). The two isolates of $P$. lateralis gave mean $\mathrm{Ct}$ values of 32.55 and 31.07 when tested with primer Pram-114F, and one isolate (ref P1728) gave a mean $\mathrm{Ct}$ value of 38.95 when tested with primer Pram-114Fc (the other P. lateralis extract was not amplified when tested using this primer). Despite giving higher Ct values for P. ramorum isolates, Pram-114Fc was chosen for completion of the comparative testing, due to the higher $\mathrm{Ct}$ values observed when testing $P$. lateralis DNA.

Assay efficiency and limit of detection. A dilution series of DNA extracted from $P$. ramorum culture was tested using the TaqMan assay incorporating forward primer $114 \mathrm{Fc}$. The response of the assay was linear down to $10 \mathrm{pg}$ (Fig. 2), and the efficiency of amplification (calculated from the slope of the standard curve as equal to $10^{(-1 / \text { slope })}-1$ ) was 0.98 . The $P$. ramorum assay incorporating primer $114 \mathrm{~F}$, and the $5.8 \mathrm{~S}$ assay, were calculated to have very similar efficiencies when tested with the same dilution series (data not shown). In order to determine whether DNA extracted from rhododendron as described above contains high levels of inhibitors, such as polyphenolics, which could adversely affect sensitivity, the dilutions also were tested with $1 \mu$ l of DNA extracted from healthy rhododendron leaf added to each reaction (Fig. 2). The rhododendron extract contained DNA at $\approx 5 \mathrm{ng} / \mu \mathrm{l}$, an amount typically observed for extracts from rhododendron leaf. A slight decrease in the efficiency of the assay was observed in the presence of rhododendron extract, calculated from the standard curve as above ( 0.88 compared with 0.98 for $P$. ramorum DNA alone); however, the $\mathrm{Ct}$ values were very similar over the range of $P$. ramorum DNA concentrations tested in the presence and absence of rhododendron DNA (Fig. 2). Amplification of P. ramorum DNA at lower concentrations became somewhat more variable and did not fall within the linear range of the assay. However, more dilute samples did give positive results; the lowest amount of DNA amplified was $5 \mathrm{pg}$ in both the presence and absence of rhododendron DNA $(\mathrm{Ct}$ values $37.87 \pm 0.57$ and $37.78 \pm 0.66$, respectively). The dilutions of $P$. ramorum DNA also were tested in multiplex for $P$. ramorum and COX in the presence of $5 \mathrm{ng}$ of rhododendron DNA per reaction and, in this case, the lowest amount of $P$. ramorum DNA amplified was $10 \mathrm{pg}$ (mean $\mathrm{Ct}$ value $38.49 \pm 0.62$ ); the efficiency was somewhat reduced (the slope of the standard curve was -4.10 , giving an efficiency of 0.75 ; the $R^{2}$ value for the curve was 0.998 ).

The sensitivity of the assay was also assessed in terms of its ability to detect $P$. ramorum in infected plant material. Necrotic tissue from $P$. ramorum-inoculated detached leaves/stem of $R$. ponticum (leaf and stem), $V$. tinus (leaf and stem), and Camellia sp. (leaf) was mixed with healthy material of the same host species and tissue type to produce samples with a total wet weight of $0.5 \mathrm{~g}$, containing $0,10,5$, and $1 \%$ necrotic tissue by weight. Samples were ground in $5 \mathrm{ml}$ of NucleoSpin C1 buffer, and for each species and tissue type, the ground sap containing $1 \%$ infected material was diluted in ground healthy sap to produce samples containing $0.1 \%$ infected material. DNA was extracted from two 300- $\mu$ l subsamples of each dilution and tested using the $P$. ramorum assay based on the Pram-114Fc primer in multiplex with the COX internal control assay. $\mathrm{COX} \mathrm{Ct}$ values ranged between $21.31( \pm 0.78)$ for $R$. ponticum stem and 24.77 $( \pm 1.51)$ for $V$. tinus leaf, indicating that the amount of amplifiable DNA that was extracted from the five host/tissue types used fell within an approximately 10-fold range. In each host and tissue type tested, $P$. ramorum could be detected down to $0.1 \%$ infected 
material, and all samples containing $1 \%$ infected material gave $\mathrm{Ct}$ values of $<36$ cycles, ranging from $33.34( \pm 0.59)$ to 35.64 $( \pm 0.31)$.

Comparative testing of plant samples. A large number of samples $(n=379)$, collected between October 2003 and February 2004 by the PHSI as part of the national P. ramorum survey of England and Wales, were used to perform a comparative test between isolation and TaqMan testing of plant material. Samples were examined for typical symptoms and four small pieces of tissue $(\approx 0.4 \mathrm{~g}$ total wet weight) were taken from the leading edge of lesions and rehydrated as described. One-half of each piece was plated out onto $\mathrm{P}_{5} \mathrm{ARP}(\mathrm{H})$, and DNA was extracted from the remaining $0.2 \mathrm{~g}$ of tissue. DNA extracts were tested by multiplex TaqMan PCR using the $P$. ramorum assay (incorporating primer Pram $-114 \mathrm{Fc}$ ) and the internal control COX assay. In order to avoid potentially ambiguous results, the real-time data was interpreted conservatively in this experiment using an arbitrary cut-off of 36 (i.e., $10 \%$ below 40 cycles); that is, a mean $\mathrm{Ct}$ value (for duplicate reactions) of $<36$ was regarded as positive whereas a mean $\mathrm{Ct}$ value of $>36$ was regarded as negative (in practice, only five samples gave mean $\mathrm{Ct}$ values above 36 ).

Of the 379 samples tested, amplifiable DNA was not extracted from 59 samples, as indicated by a negative internal control (COX) result. These samples were representative of the range of plant taxa tested; no plant species were encountered from which we were consistently unable to recover DNA. Such a result indicates that initial testing has been inconclusive and that further testing (re-extraction or resampling) is required in order to obtain a valid real-time PCR result. However, it was not possible to carry out re-extraction as part of this survey; therefore, because testing was incomplete for these samples, they were considered separately from the 320 samples from which amplifiable DNA was obtained. $P$. ramorum was isolated from 1 of the 59 COX-negative samples, and a Phytophthora sp. other than $P$. ramorum was isolated from a further 5 of these samples (no Phytophthora infection was detected in the remaining 53 samples).

Extraction of DNA, as indicated by amplification with the COX assay, followed by real-time PCR testing was completed for 320 samples. Most of the samples tested were rhododendron (219 samples) and viburnum (54 samples). In addition, DNA was extracted successfully from a further 47 samples from 17 different plant taxa as follows (numbers in parentheses indicate number of samples tested): Camellia $(n=4)$, Corylus $(n=4)$, Hamamelis $(n=3)$, Hydrangea $(n=1)$, Kalmia $(n=3)$, Leucothoe $(n=1)$, Peronskia $(n=1)$, Phygelius $(n=1)$, Picea $(n=1)$, Pieris $(n=$ $11)$, Quercus $(n=1)$, Sambucus $(n=1)$, Syringa $(n=4)$, Taxus $(n=6)$, Thuja $(n=1)$, unknown $(n=1)$, and Vaccinium $(n=3)$.

All of the samples on which $P$. ramorum was identified (realtime PCR Ct value $<36$ or successful isolation) were either rhododendron or viburnum. For these samples, mean $P$. ramorum $\mathrm{Ct}$ values were $29.32 \pm 3.19$ for rhododendron and $27.10 \pm 2.47$ for viburnum. Results were compared for all 320 samples for which testing was completed: 25 samples gave positive results with both methods, whereas 291 samples gave negative results with both methods. Of the remaining four samples, two (both rhododendron) were negative by real-time PCR but positive by isolation, whereas two (one rhododendron and one viburnum) were negative by isolation but positive by real-time PCR (Table 3). When the diagnostic sensitivity and specificity were calculated for these samples (92.59 and 99.32\%, respectively) (Table 3), they showed that the real-time PCR method was highly specific and sensitive, giving few false-positive and false-negative results when the isolation technique was used as a baseline.

Further efforts to isolate $P$. ramorum from the two samples that gave positive results by real-time PCR and negative results by initial isolation revealed that $P$. ramorum was present in both samples. In one case, $P$. ramorum was found by baiting the sample (a desiccated rhododendron shoot) in Petris mineral solution (8) with a healthy rhododendron leaf bait. For the second (viburnum), $P$. ramorum was identified following extended incubation of the isolation plate. These results suggest that the use of real-time PCR could be beneficial when testing samples in poor condition from which isolation may not be immediately successful; for example, samples collected at certain times of year (7). Further testing of the remaining two samples, which were positive by isolation but negative by PCR, was not possible because insufficient material remained after the initial testing.

Of the 187 rhododendron samples that gave negative results for $P$. ramorum, another Phytophthora sp. (most commonly $P$. cactorum) (P. Beales, CSL, U.K., personal communication) was detected by isolation from 39 samples (no Phytophthora infection was detected in the remaining 148 samples). In each case, these gave negative results using real-time PCR, illustrating the specificity of the primers.

\section{DISCUSSION}

This article reports the development and evaluation of a realtime PCR assay based on TaqMan chemistry for the detection of $P$. ramorum directly from common U.K. ornamental hosts, and for specific identification of $P$. ramorum isolated into culture. The assay was subjected to a parallel evaluation alongside a standard isolation technique and was shown to be suitably specific and sensitive for the detection of $P$. ramorum in infected plant material.

Currently, a common technique for detection of $P$. ramorum from plant material is to isolate the pathogen by culturing on semiselective media. This technique is time consuming and results in a delay of 6 to 9 days from when samples are received in the laboratory to when a result is available. Methods based on PCR allow direct detection of the pathogen from plant material; however, methods published to date may not be suited to largescale use in a routine testing laboratory. Methods based on conventional PCR $(10,18)$ require the time-consuming step of gel electrophoresis and, being open-tube systems, are potentially susceptible to post-PCR contamination. A method for P. ramorum detection based on real-time PCR has been published (12) which has a number of advantages over conventional PCR. However, this method relies on a nested-PCR approach which is relatively time consuming and could be prone to contamination problems, and these drawbacks could restrict its use for high-throughput testing. The routine molecular testing of large numbers of samples also requires a rapid and simple DNA extraction method. A method was developed that would enable specific detection of $P$. ramorum in a single round of PCR, making the amplification a closed-tube system, and TaqMan chemistry was employed to enable simple interpretation using $\mathrm{Ct}$ values alone. An extraction method was used that allows rapid and simple extraction, without

TABLE 3. Comparison of the real-time polymerase chain reaction (PCR) (TaqMan) method with isolation into culture for the detection of Phytophthora ramorum $^{\text {a }}$

\begin{tabular}{|c|c|c|c|c|c|c|}
\hline & \multicolumn{6}{|c|}{ Culture isolation } \\
\hline & & + & & & - & Total \\
\hline \multirow{5}{*}{$\begin{array}{l}\text { Real-time PCR } \\
\text { (Taqman) }\end{array}$} & + & 25 & & & \multirow[t]{2}{*}{2} & \multirow{2}{*}{27} \\
\hline & & & $A$ & $B$ & & \\
\hline & & \multirow{2}{*}{\multicolumn{2}{|c|}{2}} & $D$ & \multirow[b]{2}{*}{291} & \multirow[b]{2}{*}{293} \\
\hline & - & & & & & \\
\hline & Total & \multicolumn{2}{|l|}{27} & & 293 & 320 \\
\hline
\end{tabular}

a Positive (+) and negative (-) results for 320 samples tested using both methods, illustrating diagnostic sensitivity $[A /(A+C)]$ and specificity $[D /(D+B)]$. Samples where DNA extracts were shown to be nonamplifiable (using the internal positive control) were excluded from the analysis. Diagnostic sensitivity $=92.59 \%$ and diagnostic specificity $=99.32 \%$. 
the use of toxic reagents such as phenol, from up to 50 samples within 2 to $3 \mathrm{~h}$.

The $P$. ramorum assay was designed using new and published sequence data from the ITS 1 region of the nrRNA gene. Because the sequences in this region are very similar for some Phytophthora spp., two primer sets were developed, one in which the forward primer (Pram-114F) matched the sequence of $P$. ramorum identically, and a second in which a single nucleotide was changed in the forward primer (Pram-114Fc), with the intention of enabling better discrimination of species with similar sequences. When concentrated DNA extracts $(\approx 10$ to $100 \mathrm{ng} / \mu \mathrm{l})$ from a large range of Phytophthora spp. were tested using the two primer sets, it was shown that the assay incorporating Pram-114F not only amplified DNA from all isolates of $P$. ramorum but also showed cross-reactivity with $P$. lateralis DNA (Ct values 32.55 and 31.07 ) (Table 1). The assay incorporating primer Pram-114F has a limit of detection of $\approx 100 \mathrm{fg}$ of $P$. ramorum DNA (28) compared with a limit of detection of 12.9 fg for the nested real-time PCR assay of Hayden et al. (12), but achieves this within a single round of realtime PCR. Both assays display similar cross-reactivity with high concentrations of $P$. lateralis DNA, both requiring in the region of $1 \mathrm{ng}$ of DNA for amplification $(12,28)$. The primer set chosen for the testing of symptomatic leaf/stem samples in comparison with isolation (Pram-114Fc and 190R) detected only one of the two $P$. lateralis extracts tested ( $\mathrm{Ct}$ value 38.95$)$, indicating that the concentration of these extracts was close to the limit of detection for $P$. lateralis. However, the nucleotide change at the $3^{\prime}$ end of this forward primer, which was introduced to achieve increased specificity $(25,29)$, resulted in the assay being somewhat less sensitive than Pram-114F, with a limit of detection for purified pathogen DNA of $\approx 5 \mathrm{pg}$ of $P$. ramorum DNA. Sensitivity experiments were performed in order to determine whether the assay incorporating Pram-114Fc would be suitable for detection of $P$. ramorum in infected plant material, despite its attenuated sensitivity compared with Pram-114F. It was shown that the assay was sufficiently sensitive to allow reliable detection of the pathogen in samples containing as little as $1 \%$ symptomatic material by weight when used in conjunction with the Nucleospin DNA extraction method described. In the United Kingdom, the assay is used to confirm the presence of pathogen in samples containing $\approx 25$ to $100 \%$ symptomatic material, which allows a good safety margin regarding sensitivity when using this DNA extraction method. The assay also detected $P$. ramorum in samples containing $0.1 \%$ infected material, with $\mathrm{Cts}$ in the range of 36.17 to 38.84. However, a high $P$. ramorum $\mathrm{Ct}$ value may be regarded as potentially ambiguous in some circumstances because, instead of indicating a sample containing a low level of $P$. ramorum, such a result could represent a sample in poor condition, surface contamination without genuine infection, cross contamination between extracts, or potentially, a very high concentration of $P$. lateralis DNA (although this is unlikely due to the narrow host range of this pathogen) (12). In practice in a routine testing laboratory, a $\mathrm{Ct}$ value between 36 and 40 should be treated as ambiguous and indicative that resampling and testing is required.

The protocol for testing plant material also incorporated an internal control assay designed to detect a gene from the host plant, the use of which aids in the interpretation of negative results, by preventing false negatives. In contrast, no such control of false negative results is available when testing by isolation because, although failure to isolate $P$. ramorum from a sample could genuinely reflect absence of the pathogen, there are a number of factors, such as the condition of the sample, which could adversely affect viability. A negative COX assay result (together with a negative $P$. ramorum result) indicates the need for re-extraction, resampling, or both in order to obtain a conclusive realtime PCR result. Amplifiable DNA was not recovered from 59 of 379 samples submitted for testing by the PHSI, indicating that, although the extraction method was successful for the majority of samples $(84 \%)$, modifications to the procedure are likely to be necessary in order to extract successfully from all samples encountered. Samples which are in poor condition (for example, highly desiccated or colonized by other organisms) may contain little intact DNA, or may contain high levels of inhibitors which could adversely affect PCR, which could cause negative COX results. This highlights a need to ensure that care is taken to sample material that will be conducive to successful extraction of amplifiable DNA; for example, taking material from the leading edge of lesions rather than severely necrotic areas. Although the simple, commercially available extraction technique used was found to be successful for extraction of DNA from the majority of samples encountered in the course of survey work in the United Kingdom, in order to take into account the expanding host range of $P$. ramorum and, in particular, the recent findings on tree species in the United Kingdom, it is likely that the DNA extraction method will have to be adapted in line with the material to be tested, particularly if the method is to be used predominantly for detection of $P$. ramorum in forest species rather than ornamental hosts.

The remaining 320 samples from which DNA was extracted successfully were tested in order to compare the $P$. ramorum/COX real-time PCR assay with a traditional isolation technique. A diverse range of hosts was tested, all of which showed dieback or leaf blight similar to the characteristic symptoms of $P$. ramorum infection. Most samples were from rhododendron (68\%), but other common natural hosts such as viburnum, camellia, and Pieris spp. were included. Less common natural hosts also were encountered, such as Hamamelis, Kalmia, Leucothoe, Vaccinium, and Syringa spp. The majority of samples were negative for $P$. ramorum using both real-time $\mathrm{PCR}$ and traditional plating (91\%), which is consistent with our experience of the proportion of samples submitted to CSL with $P$. ramorum-like symptoms in which $P$. ramorum is not detected. In this study, $P$. ramorum was identified only in rhododendron and viburnum samples, reflecting the fact that these were the predominant hosts in the United Kingdom at the time of the study. However, P. ramorum has been identified, using the DNA extraction and real-time PCR method described, in inoculated and naturally infected plants of a number of other species (including artificially inoculated Taxus baccata and a Camellia sp.; data not shown). The COX internal control assay has been used to confirm the successful extraction of PCRamplifiable DNA, using the method described, from a range of other potential hosts sampled in this study (including Corylus, Hamamelis, Hydrangea, Kalmia, Leucothoe, Peronskia, Phygelius, Picea, Pieris, Quercus, Sambucus, Syringa, Thuja, and Vaccinium spp.). Infected material was not available for these hosts; however, because PCR-amplifiable plant DNA was extracted successfully, it is likely that pathogen DNA also could be extracted from these species using the same method.

Direct real-time PCR testing of plant material offers the potential to reduce testing times from 6 to 9 days to 1 to 2 days, as well as overcoming concerns about isolation as a reliable detection method from old, dried out, or dirty samples. Real-time PCR testing of plant material, however, does not ascertain pathogen viability, only the presence of its DNA. A move toward disease control as opposed to eradication may see the increased use of pesticides to suppress symptoms and protect plants; this will affect viability but not the presence of $P$. ramorum DNA and, therefore, direct real-time PCR testing of plant material alone may not always be appropriate. However, real-time PCR has the potential to allow large numbers of samples to be screened quickly and cheaply, especially if the majority of samples are likely to be negative. In the United Kingdom, $<25 \%$ of samples submitted for $P$. ramorum testing are positive for $P$. ramorum confirmatory testing by isolation of real-time PCR positives could be used as a viability check if required for these, thus significantly reducing overall costs and time to deliver re- 
sults. The method described here should prove to be extremely useful in survey work, in identification of $P$. ramorum in single samples, and in investigating many aspects relating to the biology of $P$. ramorum.

\section{ACKNOWLEDGMENTS}

Funding for this work was provided by Plant Health Division of Defra and work was performed under license number PHL 251A/4736 (03/2004). We thank all those who supplied isolates (Table 1), as well as V. Barton, P. Beales, I. Barker, G. Budge, E. Hobden, P. Giltrap, L. Walker, and $\mathrm{K}$. Walsh at CSL for their invaluable laboratory and editorial support.

\section{LITERATURE CITED}

1. Anonymous. 2002. Commission Decision (2002/757/EC) of 19 September 2002 on provisional emergency phytosanitary measures to prevent the introduction into and the spread within the Community of Phytophthora ramorum Werres, De Cock \& Man in 't Veld sp. nov. Off. J. Eur. Communities 2002-09-20, L 252:3739.

2. Beales, P. A., Brokenshire, T., Barnes, A. V., Barton, V. C., and Hughes, K. J. D. 2004. First report of ramorum leaf blight and dieback (Phytophthora ramorum) on Camellia spp. in the UK. Plant Pathol. 53:524.

3. Beales, P. A., Schlenzig, A., and Inman, A. J. 2004. First report of ramorum bud and leaf blight (Phytophthora ramorum) on Syringa vulgaris in the UK. Plant Pathol. 53:525.

4. Brasier, C., Denman, S., Brown, A., and Webber, J. 2005. Sudden oak death (Phytophthora ramorum) discovered in trees in Europe. Mycol. Res. 108:1108-1110.

5. Brasier, C. M., Denman, S., Rose, J., Kirk, S. A., Hughes, K. J. D., Griffin, R. L., Lane, C. R., Inman, A. J., and Webber, J. F. 2004. First report of ramorum bleeding canker on Quercus falcata, caused by Phytophthora ramorum. Plant Pathol. 53:804.

6. Davidson, J. M., Werres, S., Garbelotto, M., Hanson, E., and Rizzo, D. M. 2003. Sudden Oak Death and associated diseases caused by Phytophthora ramorum. Plant Health Progress doi:10.1094/PHP-2003-0707-01DG.

7. Davidson, J. M., Wickland, A. C., Patterson, H. A., Falk, K. R., and Rizzo, D. M. 2005. Transmission of Phytophthora ramorum in mixedevergreen forest in California. Phytopathology. 95:587-596.

8. Erwin, D. C., and Ribeiro, O. K. 1996. Page 89 in: Phytophthora Diseases Worldwide, Chapter 3. The American Phytopathological Society, St. Paul, MN.

9. Gachon, C., Mingam, A., and Charrier, B. 2004. Real-time PCR: What relevance to plant studies? J. Exp. Biol. 55:1445-1454.

10. Garbelotto, M., Rizzo, D. M., and Hayden, K. 2002. Phytophthora ramorum and sudden oak death in California: III. Pathogen genetics. Pages 765-774 in: Proc. 5th Oak Symp.: Oaks in California's Changing Landscape. R. Standiford, D. McCreary, and K. B. Purcell, eds. U.S. Dep. Agric. For. Serv. Gen. Tech. PSW-GTR-184.

11. Giltrap, P. M., Inman, A. J., Barton, V. C., Barnes, A. V., Lane, C. R., Hughes, K. J. D., Tomlinson, J., Dean, M. L., and Lizzard, K. 2004. First report of ramorum dieback (Phytophthora ramorum) on Hamamelis virginiana in the UK. Plant Pathol. 53:526.

12. Hayden, K. J., Rizzo, D., Tse, J., and Garbelotto, M. 2004. Detection and quantification of Phytophthora ramorum from Californian forests using a real-time polymerase chain reaction assay. Phytopathology 94:1075-1083.

13. Hughes, K. J. D., Fulton, C. E., McReynolds, D., and Lane, C. R. 2000. Development of new PCR primers for identification of Monilinia species. Bull. OEPP/EPPO Bull. 30:507-511

14. Inman, A. J., Townend, V. C., Barnes, A. V., Lane, C. R., Hughes, K. J. D., Griffin, R. L., and Eales, S. J. 2003. First report of ramorum dieback (Phytophthora ramorum) on Pieris in England. Plant Pathol. 52:785.

15. Ivors, K. L., Hayden, K. J., Bonants, P. J. M., Rizzo, D. M., and Garbelotto, M. 2004. AFLP and phylogenetic analyses of North American and European populations of Phytophthora ramorum. Mycol. Res. 108:378-392.

16. Jeffers, S. N., and Martin, S. B. 1986. Comparison of two media selective for Phytophthora and Pythium species. Plant Dis. 70:1038-1043.

17. Kong, P., Hong, C. X., Tooley, P. W., Ivors, K., Garbelotto, M., and Richardson, P. A. 2004. Rapid identification of Phytophthora ramorum using PCR-SSCP analysis of ribosomal DNA ITS-1. Lett. Appl. Microbiol. 38:433-439.

18. Lane, C. R., Barnes, A. V., Beales, P. A., Griffin, R. L., Hughes, K. J. D., Inman, A. J., Townend, V. C., Brasier, C. M., and Webber, J. W. 2003. First report of Phytophthora ramorum in the UK. Paper 19.35 in: 8th Int. Congr. Plant Pathol. Christchurch, New Zealand. Volume 2:265.

19. Lane, C. R., Beales, P. A., Hughes, K. J. D., Griffin, R. L., Munro, D., Brasier, C. M., and Webber, J. W. 2003. First outbreak of Phytophthora ramorum in England, on Viburnum tinus. Plant Pathol. 52:414.

20. Lane, C. R., Beales, P. A., Hughes, K. J. D., Tomlinson, J. A., Inman, A. J., and Warwick, K. 2004. First report of ramorum dieback (Phytophthora ramorum) on container-grown English yew (Taxus baccata) in England. Plant Pathol. 53:522.

21. Martin, F. N., and Tooley, P. W. 2004. Identification of Phytophthora isolates to species level using restriction fragment length polymorphism analysis of a polymerase chain reaction-amplified region of mitochondrial DNA. Phytopathology 94:983-991.

22. Martin, F. N., Tooley, P. W., and Blomquist, C. 2004. Molecular detection of Phytophthora ramorum, the casual agent of sudden oak death in California and two additional species commonly recovered from diseased plant material. Phytopathology 94:621-631.

23. Ratti, C., Budge, G., Ward, L., Clover, G., Rubies-Autonell, C., and Henry, C. 2004. Detection and quantification of soil borne cereal mosaic virus and Polymyxa graminis in winter wheat using real-time PCR (TaqMan). J. Virol. Methods 122:95-103.

24. Rizzo, D. M., Garbelotto, M., Davidson, M., Slaughter, J. M., and Koike, G. W. 2002. Phytophthora ramorum as the cause of extensive mortality of Quercus spp. and Lithocarpus densiflorus in California. Plant Dis. 86:205-214.

25. Rust, S., Funke, H., and Assmann, G. 1993. Mutagenically separated PCR (MS-PCR) - a highly specific one-step procedure for easy mutation detection. Nucleic Acids Res. 21:3623-3629

26. Sansford, C., Jones, D., and Brasier, C. 2003. Pest risk analysis: Phytophthora ramorum. Published online by the Department for Environment, Food and Rural Affairs (DEFRA). http://www.defra.gov.uk/planth/ pra/sudd.pdf.

27. Schaad, N. W., and Frederick, R. D. 2002. Real-time PCR and its application for rapid plant disease diagnostics. Can. J. Plant Pathol. 24:250-258.

28. Tomlinson, J. A., Boonham, N., Hughes, K. J. D., Griffin, R. L., and Barker, I. 2005. On-site DNA extraction and real-time PCR for detection of Phytophthora ramorum in the field. Appl. Environ. Microbiol. 71:6702-6710

29. Walsh, K., Korimbocus, J., Boonham, N., Jennings, P., and Hims, M. 2005. Using real-time PCR to discriminate and quantify the closely related wheat pathogens Oculimacula yallundae and Oculimacula acuformis. J. Phytopathol. 153:715-721.

30. Ward, L., Fenn, M., and Henry, C. 2004. A rapid method for detection of Polymyxa DNA in soil. Plant Pathol. 53:485-490.

31. Weller, S. A., Elphinstone, J. G., Smith, N. C., Boonham, N., and Stead, D. E. 2000. Detection of Ralstonia solanacearum strains with a quantitative, multiplex, real time, fluorogenic PCR (TaqMan) assay. Appl. Environ. Microbiol. 66:2853-2858.

32. Werres, S., and de Merlier, D. 2003. First detection of Phytophthora ramorum mating type A2 in Europe. Plant Dis. 87:1266.

33. Werres, S., Marwitz, R., Man in 't Veld, W. A., De Cock, W. A. M., Bonants, P. J. M., De Weerdt, M., Themann, K., Ilieva, E., and Baayen, R. P. 2001. Phytophthora ramorum sp. nov., a new pathogen on Rhododendron and Viburnum. Mycol. Res. 105:1155-1165.

34. Žerjav, M., Munda, A., Lane, C. R., Barnes, A. V., and Hughes, K. J. D. 2004. First report of Phytophthora ramorum on container-grown plants of rhododendron and viburnum in Slovenia. Plant Pathol. 53:523. 